NUSANTARA : Jurnal Ilmu Pengetahuan Sosial - Vol. 6 No 1 (2019) ( Januari - Juni ) issn online : $2550-0813$ issn cetak : $2541-657 \mathrm{X}$

http://jurnal.um-tapsel.ac.id/index.php/nusantara

\title{
HUBUNGAN ANTARA KINERJA GURU DAN PRESTASI BELAJAR PESERTADIDIK PADA MATA PELAJARAN PKn KOMPETENSI DASAR HAKIKATDEMOKRASI KELAS VIII SMP NEGERI 8 PADANGSIDIMPUAN
}

\author{
Yusmiati, \\ yusmiati@um-tapsel.ac.id \\ Dosen FKIP Universitas Muhammadiyah Tapanuli Selatan
}

\begin{abstract}
Abstrak
Hubungan antara kinerja guru dan prestasi belajar peserta didik pada mata pelajaran PKn kompetensi dasar Hakekat demokrasi kelas VIII SMP Negeri 8 Padangsidimpuan. Rumusan masalah dalam penelitian ini adalah Apakah Ada Hubungan Antara Kinerja Guru dan Prestasi Belajar Peserta Didik Pada Mata Pelajaran PKn kompetensi dasar Hakikat Demokrasi kelas VIII SMP Negeri 8 Padangsidimpuan?. Sedangkan tujuan penelitian ini untuk membahas Hubungan Antar Kinerja Guru dan Prestasi Belajar Peserta Didik Pada Mata Pelajaran PKn kompetensi dasar hakikat demokrasi kelas VIII SMP Negeri 8 Padangsidimpuan.
\end{abstract}

Adapun metode penelitian yang digunakan adalah penelitian Asosiatif, yaitu untuk mengetahui hubungan antara dua variabel atau lebih, dengan pendekatan penelitian lapangan (Field research) dan penelitian kepustakaan (library research).Adapun rumus yang dipergunakan untuk menguji hipotesis dalam penelitian ini adalah rumus korelasi Product moment yaitu:

$$
r_{x y}=\frac{\sum_{x y}}{\sqrt{\left(\sum x^{2}\right)\left(\sum y^{2}\right)}}
$$

Dari hasil perhitungan koefesien korelasi maka diperoleh $r=0.987$. Jika angka indeks korelasi tersebut di korelasikan dengan " $\mathrm{r}$ " tabel product moment maka di dapat bahwa pada taraf signifikan 5\% dengan $\mathrm{N}=30$ diperoleh 0.021 . Dengan demikian dapat diketahui bahwa nilai r hitumg lebih besar daripada r tabelyakni : 0.987>0.021. 


\section{NUSANTARA : Jurnal Ilmu Pengetahuan Sosial - Vol. 6 No 1 (2019) ( Januari - Juni ) issn online : $2550-0813$ issn cetak : $2541-657 \mathrm{X}$ http://jurnal.um-tapsel.ac.id/index.php/nusantara}

Maka dapat disimpulkan bahwa Ada Hubungan Antara Kinerja Guru dan Prestasi Belajar Peserta Didik Pada Mata Pelajaran PKn kompetensi dasar Hakikat Demokrasi kelas VIII SMP Negeri 8 Padangsidimpuan.

\section{Pendahuluan}

\section{Berkembangnya kualitas} pendidikan tidak lepas dari peran kinerja para guru. Tanpa kinerja guru yang baik maka pencapaian kualitas pendidikan akan sulit untuk dicapai. Dalam hal ini peran pemerintah sangat diperlukan untuk peningkatan kinerja guru tersebut. Selain itu potensi kualitas pendidikan juga tidak bisa dikesampingkan, karena dua hal tersebut sangat penting untuk majunya pendidikan.

Di Indonesia sendiri peran pemerintah direalisasikan dengan terbitnya undang-undang No 20 tahun 2003 pasal 27 tentang sistem pendidikan Nasional, yang mana untuk menata kembali (meratifikasi) dunia pendidikan Indonesia.Sistim pendidikan nasional lebih mempertajam kualitas pendidikan baik pada penataan kebijakan, penataan kelembagaan dan penataan tenaga kependidikan.

\begin{tabular}{|c|c|c|}
\hline$n$ & rangka & melak \\
\hline Unda & tersebut & pel \\
\hline meg & Pera & \\
\hline$\lambda$ & & \\
\hline & & \\
\hline
\end{tabular}

mencakup standart: isi, proses, kompetensi lulusan, pendidik dan tenaga pendidikan, sarana dan prasarana, pengelolaan pembiayaan dan standar penilaian pendidikan. Keberhasilan suatu pendidikan dipengaruhi diantaranya oleh faktor tenaga pendidikan, kurikulum, sarana dan prasaran, peserta didik.

$$
\text { Penilaian tentang kinerja guru }
$$
semakin penting ketika lembaga akan melakukan reposisi. Artinya bagaimana lembaga harus mengetahui faktor-faktor apa saja yang mempengaruhi kinerja guru. Hasil analisis akan bermanfaat untuk membuat program pengembangan SDM guru secara optimal dan hal itu sangat diperlukan untuk memajukan mutu pendidikan.

$$
\text { Guru haruslah memiliki }
$$
kepribadian sejati. Menurut Markasid mengatakan bahwa : "Kepribadian sejati berhubungan dengan kepribadian yang ditunjang oleh penemuan visi, kepemimpinan dan pengelolaan diri yang baik. Keadaan guru di Indonesia amat memprihatinkan”. Kebanyakan guru belum memiliki profesionalisme yang memadai untuk menjalankan tugasnya 


\section{NUSANTARA : Jurnal Ilmu Pengetahuan Sosial - Vol. 6 No 1 (2019) ( Januari - Juni ) issn online : $2550-0813$ issn cetak : $2541-657 \mathrm{X}$ http://jurnal.um-tapsel.ac.id/index.php/nusantara}

sebagaimana disebut dalam pasal 39 UU No 20/2003 yaitu merencanakan pembelajaran, melaksanakan pembelajaran, menilai hasil pembelajaran, melakukan pembimbingan, melakukan pelatihan, melakukan penelitian dan melakukan pengabdian masyarakat.

Guru merupakan komponen yang paling berpengaruh terhadap terciptanya proses dan hasil pendidikan yang berkualitas. Oleh karena itu upaya perbaikan apapun yang dilakukan untuk meningkatkan kualitas pendidikan tidak akan memberikan sumbangan yang signifikan tanpa di dukung oleh guru yang profesional dan berkualitas. Guru benarbenar di tuntut untuk memiliki kinerja yang tinggi.

Dengan kinerja tinggi maka tingkat sumber daya manusia di Indonesia akan mulai sedikit demi sedikit meningkatkan terutama para generasi muda Indonesia. Sehingga terciptalah bangsa yang cerdas dan mampu menghadapi tantangantantangan masa depan. Guru memikul tugas dan tanggung jawab yang tidak ringan.di samping itu dia harus membuat pinter anak peserta didiknya secara akal, (mengasah kecerdesan IQ).

Keberhasilan pendidikan sebagian besar di tentukan oleh kinerja guru. Baik kinerja guru dalam perencanaan pembelajaran, kinerja guru dalam pelaksanaan pembelajaran, kinerja guru dalam evaluasi pembelajaran, serta kinerja guru dalam disiplin tugas.Saat ini kinerja guru di Indonesia masih banyak mengalami kekurangan terutama dalam kompetensi dan kemampuannya dalam mengajar, hal inilah yang secara tidak langsung sangat mempengaruhi kualitas pendidikan di Indonesia. Guru sebagai penopang utama pendidikan seharusnya sudah harus bisa menjadi profesional dan memiliki kompetensi yang bagus agar dapat menghasilkan peserta didik yang berkualitas.

Pemerintah sebagai pemegang kekuasaan di negeri ini sudah sepantasnya mengatur segala kebijakan yang bisa meningkatkan kinerja guru tersebut ,dengan adanya peraturan dan perundangundangan yang telah ditetapkan pemerintah sudah memiliki senjata yang ampuh untuk menggerakkan para guru agar bisa lebih profesional dan meningkatkan kinerjanya serta prestasi belajar peserta didiknya. Khususnya pemerintah daerah setempat dengan menganggarkan sebagian anggaran Daerah untuk menunjang berkembangnya pendidikan. 


\section{NUSANTARA : Jurnal Ilmu Pengetahuan Sosial - Vol. 6 No 1 (2019) ( Januari - Juni ) issn online : $2550-0813$ issn cetak : $2541-657 \mathrm{X}$ http://jurnal.um-tapsel.ac.id/index.php/nusantara}

Berdasarkan pengamatan penulis, bahwa di SMP Negeri 8 Padangsidimpuan tahun pelajaran 2015\2016: peserta didik masih ada yang kurang tertarik untuk belajar PKn, aktifitas belajar masih rendah, dan prestasi belajar pada mata pelajaran PKn belum maksimal. Dugaan sementara hal ini berhubungan dengan kinerja guru.

Berdasarkan uraian di atas, peneliti merasa tertarik untuk mengambil topik: "Hubungan Antar Kinerja Guru Terhadap Prestasi Belajar Peserta Didik Pada Mata Pelajaran Pkn Kompetensi Dasar Hakikat Demokrasi Dikelas VIII Negeri 8 Padangsidimpuan

\section{Metode Penelitian}

Sebelum penulis melakukan penelitian dilapangan untuk membuktikan hipotesis penulis mengadakan pendekatan penelitian dengan melalui penelitian kepustakaan (Library Research) dan penelitian lapangan (Field Research). Penelitian yang dilakukan dengan cara melakukan penyebaran angket dan tes secara langsung ke lokasi penelitian yaitu SMP Negeri 8 Padangsidimpuan. Adapun gambaran kedua variabel tersebut adalah kinerja guru (variabel $\mathrm{X}$ ), prestasi belajar peserta didik materi hakikat demokrasi (variabel Y). Jumlah populasi penelitian ini adalah seluruh peserta didik yang brjumlah 30 peserta didik di SMP Negeri 8 Padangsidimpuan Tahun Pelajaran 20152016. Jumlah sampel yang di ambil 30 peserta didik dari kelas VIII-8 yang jumlah populasi 355.

Responden penelitian yaitu orang yang dapat merespon, memberikan informasi tentang data penelitian”. Responden merupakan sumber informasi, responden dalam penelitian ini yakni: peserta didik kelas VIII, kepala sekolah, dan guru-guru.

Jenis penelitian yang digunakan di dalam penelitian ini adalah penelitian asosiatif yaitu bertujuan untuk mengetahui hubungan antara dua variabel atau lebih. Adapun variabel yang akan diteliti dalam penelitian ini adalah variabel $\mathrm{X}$ yaitu kinerja guru dan variabel Y yaitu prestasi belajar peserta didik pada kompetensi dasar Hakekat demokrasi.

Teknik pengumpulan data yang penulis gunakan dalam penelitian ini adalah berupa angket dan tes. angket dipergunakan untuk memperoleh data tentang variabel $\mathrm{X}$, dan tes dipergunakan untuk memperoleh data tentang variabel $\mathrm{Y}$.

\section{Hasil dan Pembahasan}

Pokok permasalahan dalam penelitian ini adalah. Apakah Ada Hubungan Antara Kinerja Guru dan 


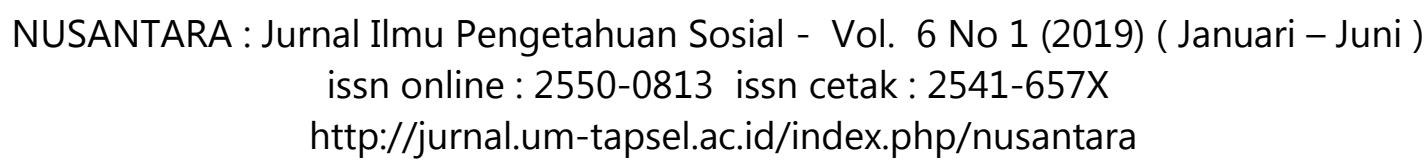

Prestasi Belajar Peserta Didik Pada Mata Pelajaran PKn kompetensi dasar Hakikat Demokrasi kelas VIII SMP Negeri 8 Padangsidimpuan? Setelah data terkumpul, selanjutnya dianalisa dengan menggunakan rumus product momen, Dari perhitungan koefesien korelasi maka diperoleh nilai hasil $\mathrm{r}$ hitung $=0.987$.

Nilai r hitung kemudian dibandingkan dengan nilai $r$ tabel, dimana $r$ hitung lebih besar dari $r$ tabel yaitu $0.987>0,021$ pada taraf kesalahan $5 \%$. dan 0.987>0,014 pada taraf kesalahan $1 \%$. Sesuai dengan dasar pengambilan keputusan bahwa : Terima Ha jika nilai r hitung lebih besar dengan nilai $r$ tabel, dan terima Ho jika nilai $\mathrm{r}$ hitung lebih kecil dari nilai r tabel.

Berdasarkan perhitungan diatas dimana $r$ hitung lebih besar dari nilai $r$ tabel, Maka Ha diterima yang berbunyi bahwa “Ada Hubungan antara Kinerja guru dan prestasi belajar peserta didik pada mata pelajaran PKn Kompetensi dasar Hakikat demokrasi kelas VIII SMP Negeri 8 Padangsidimpuan Sedangkan Ho, di tolak yang berbunyi “Tidak ada Hubungan antara Kinerja guru dan prestasi belajar peserta didik pada mata pelajaran PKn Kompetensi dasar Hakikat demokrasi dikelas VIII-8 SMP Negeri 8 Padangsidimpuan. Berdasarkan perhitungan tersebut dapat disimpulkan bahwa hiposis yang penulis ajukan diterima kebenarannya.

\section{Kesimpulan}

Berdasarkan data yang diperoleh dan selanjutnya perhitungan koefisien korelasi . Maka diperoleh hasil $\mathrm{r}$ hitung = 0.987 hasil ini kemudian dibandingkan dengan $r$ tabel dimana $r$ hitung lebih besar dari r tabel yaitu $0.987>0.021(5 \%)$ dan $0.987>0.014$ (1\%) maka dapat dikatakan bahwa ada Hubungan antara Kinerja guru dan prestasi belajar peserta didik pada mata pelajaran PKn Kompetensi dasar Hakikat demokrasi dikelas VIII-8 SMP Padangsidimpuan.

\section{Saran}

Pada bagian akhir dari penulisan ini, penulis mengajukan berbagai saran demi perbaikan kedepan, yaitu :

1. Kepada peserta didik yang merupakan subjek belajar untuk lebih meningkatkan penguasaan terhadap materi pelajaran sehingga penguasaan pembelajaran dapat tercapai dengan baik 
NUSANTARA : Jurnal Ilmu Pengetahuan Sosial - Vol. 6 No 1 (2019) ( Januari - Juni ) issn online : $2550-0813$ issn cetak : $2541-657 \mathrm{X}$ http://jurnal.um-tapsel.ac.id/index.php/nusantara

2. Kepada guru yang mengajar diharapkan dapat meningkatkan kemampuan dalam mengajar dan selalu memperhatikan serta memotivasi siswa dalam kegiatan belajar pembelajaran. Di samping itu guru diharapkan dapat memahami permasalahan yang di hadapi peserta didik sehingga prestasi belajar peserta didik dapat meningkat dengan baik.

3. Bagi calon guru (mahasiswa), agar lebih giat lagi dalam belajar sehingga bisa meningkatkan ilmu pengetahuannya sehingan pencapaian pembelajaran dapat meningkat.

4. Sebagai bahan masukan bagi peneliti lainnya yang akan mengadakan penelitian pada permasalahan yang sama, guna memperkokoh data-data lain sehingga diperoleh hasil yang lebih baik dan bermanfaat.

\section{Daftar Pustaka}

Ahmad, 2010,Kiat Menjadi Guru Profesional. Yogyakarta: AR. Ruzz Media Group

Anas Sudjiono, 2006, Pengantar Statistik Pendidikan, Jakarta: Rajawali Press

Anwar,2007,Pengantar Statistik
Arief Furchan, 2006, Pengantar Penelitian Dalam Pendidikan, Surabaya: Usaha Nasional

Badan independen National Council for Accreditation of Teacher Education Tilaar, 2006

Kartini Kartono, 2007.Pengantar Metodeologi Research Sosial, Bandung: Alumni

Markasid. Kebijakan Peningkatan Kualitas Tenaga Pendidikan. Jurnal Kependidikan Volume 1, Nomor 1. Diunduh dari. 2009

Mohammad Ali,2007. Metodologi Penelitian, Jakarta: Rineka Cipta

Mohammad Ali,2005. Belajar dan pembelajaran, Jakarta: Rineka Cipta

Nurdin, Muhammmad, 2010. Kiat Menjadi Guru Profesional. Yogyakarta: AR. Ruzz Media Group

Peraturan Pemerintah Nomor 74 Tahun 2008 tentang Guru Pasal 52 ayat (1)

Poerwadarminta dalam Kamus Besar bahasa Indonesia

Purwanto, M. Ngalim, 2007, Psikologi Pendidikan. Bandung: PT Remaja Rosdakarya

Pendidikan, Jakarta: Rajawali Press 
NUSANTARA : Jurnal Ilmu Pengetahuan Sosial - Vol. 6 No 1 (2019) ( Januari - Juni ) issn online : $2550-0813$ issn cetak : $2541-657 \mathrm{X}$ http://jurnal.um-tapsel.ac.id/index.php/nusantara

Undang-Undang PP No. 19 tahun 2004

Tentang system Pendidikan nasional

Winarno Surakhmad, 2008,Pengantar Interaksi Mengajar Belajar, Dasar dan Teknik Metodologi Pengajaran, Bandung: Tarsito

Suharsimi Arikunto, 2006, Prosedur Penelitian Suatu Pendekatan Praktik, Jakarta: Rineka Cipta

Suharsimi Arikunto, 2007,Prosedur Penelitian Suatu Pendekatan Praktik, Jakarta: Rineka Cipta

Sia Tjundjing, Hubungan Antara IQ, EQ, dan QA dengan Prestasi Studi Pada Peserta didik SMU, 2007Jakarta : PT. RajaGrafindo Persada

Soejanto, 2009,Psikologi Umum, Jakarta: PT Rineka Cipta

Surya Sumantri, 2006,Penelitian Kependidikan, Prosedur dan Strategi, Bandung: Angkasa

Surya Sumantri, 2006,Penelitian Kependidikan, Prosedur dan Strategi, Bandung: Angkasa

Suharsimi Arikunto, 2010, Manajemen Penelitian, Jakarta: Rineka Cipta

Sukardi, 2010,Metodologi Penelitian Pendidikan, Jakarta:Bumi Aksara
Suharsimi Arikunto,2010. Manejemen

Penelitian, Jakarta: Rineka Cipta 